\title{
APENDICITE AGUDA: EXISTE RELAÇÃO ENTRE O GRAU EVOLUTIVO, IDADE E O TEMPO DE INTERNAÇÃO?
}

\author{
ACUTE APPENDICITIS: IS THERE A RELATION BETWEEN THE EVOLUTION PHASE, \\ AGE AND HOSPITAL LENGTH OF STAY?
}

\author{
Carlos Augusto Fischer ${ }^{\text {; }}$ Mauro de Souza Leite Pinho, TCBC-SC ${ }^{2}$; Sérgio Ferreira ${ }^{3}$; \\ Celso Augusto Cardoso Milani ${ }^{1}$; Charles Ronald van Santen ${ }^{1}$; Richard Andrei Marquardt ${ }^{1}$
}

\begin{abstract}
RESUMO: Objetivos: Identificar uma possível relação entre o grau evolutivo da apendicite aguda, a idade cronológica e a duração do período de internação. Método: Análise retrospectiva de 272 pacientes submetidos à apendicectomia quanto ao grau evolutivo da apendicite e seu respectivo período de internação. A evolução do processo inflamatório foi classificada pelo exame histopatológico em quatro graus: catarral, flegmonosa, supurativa e gangrenosa. Resultados: A distribuição quanto ao sexo mostrou maior incidência em homens, com 193 casos (70\%) e a média de idade foi de 29 anos. O período médio de internação foi de 4,3 dias. A incidência dos diferentes graus evolutivos foi de 88 casos (32,3\%) para o tipo catarral, 79 (29\%) flegmonosa, 70 (25,7\%) supurativa e 35 $(12,8 \%)$ gangrenosa. A análise da média de idade e tempo de internação relacionados ao grau evolutivo da apendicite aguda, respectivamente, foi de 27,9 anos e 3,7 dias (catarral), 28,4 anos e 3,9 dias (flegmonosa), 30,1 anos e cinco dias (supurativa) e 35 anos e 5,2 dias (gangrenosa). Ao agruparmos os graus obtivemos as médias de 28,1 anos e 3,8 dias para os tipos catarral/flegmonosa e 30,7 anos e cinco dias para supurativa/gangrenosa. Foi observada uma correlação significativa entre o grau de evolução da apendicite e o tempo de internação $(\mathrm{p}=0.01)$ e entre a idade e o grau evolutivo $(\mathrm{p}=0.01)$. Conclusões: Pacientes portadores de graus evolutivos mais avançados de apendicite aguda situam-se em faixa etária mais elevadas e tem tempo de internação mais prolongado (Rev. Col. Bras. Cir. 2005; 32(3): 136-138).
\end{abstract}

Descritores: Apendicite; Doença aguda; Tempo de internação; Grupos etários.

\section{INTRODUÇÃO}

A apendicite aguda é uma doença freqüente e a apendicectomia uma das cirurgias mais realizadas em todo o mundo. Sua maior incidência ocorre em adultos jovens, no sexo masculino e em indivíduos da raça branca. Embora controversa, a teoria mais aceita para sua etiologia é a obstrução apendicular aguda, seja por hiperplasia linfática, fecalito ou corpo estranho.

Estudos mostram que está relacionada a um pior prognóstico em pacientes mais idosos e com doenças associadas ${ }^{1}$, assim como a um maior tempo de evolução da doença e à ocorrência de perfuração apendicular ${ }^{2}$

O presente estudo tem por objetivo identificar uma possível relação entre o grau evolutivo da apendicite aguda, a idade cronológica e o tempo de internação hospitalar dos pacientes.

\section{MÉTODO}

Durante o período de agosto de 1998 a março de 2003 foram realizadas um total de 382 apendicectomias no Departamento de Cirurgia do Hospital Municipal São José, em Joinville, SC. A partir deste grupo, procedeu-se à análise retrospectiva de 272 pacientes (71\%) com relação à idade, sexo, tempo de internação hospitalar e grau evolutivo da apendicite segundo avaliação histopatológica. Para este fim, foram os espécimes cirúrgicos classificados como: apendicite catarral, flegmonosa, supurativa ou gangrenosa.

Os resultados obtidos em cada grupo de pacientes foram comparados, para fins estatísticos, utilizando-se o teste $\mathrm{t}$ de Student.

\section{RESULTADOS}

Do total de 272 pacientes, 193 (70\%) pertenciam ao sexo masculino. A idade variou de 13 a 77 anos (média de 29 anos). A distribuição da doença segundo a faixa etária é mostrada no Gráfico 1. O tempo médio de internação foi de 4,3 dias (dois a 36 dias).

Quanto ao grau evolutivo da apendicite observouse a fase catarral em 88 pacientes $(32,3 \%)$, fase flegmonosa em $79(29 \%)$, fase supurativa em $70(25,3 \%)$ e fase gangrenosa em $35(12,8 \%)$.

A idade e o tempo de internação médios de cada subgrupo de pacientes segundo o grau evolutivo da apendicite está apresentado na Tabela 1.

Para melhor caracterização do estágio evolutivo, dividimos os pacientes em dois grupos principais: apendicites não-complicadas (apendicite catarral + flegmonosa) e apendicites complicadas (apendicite supurativa + gangrenosa). A

1. Cirurgião Geral, Ex-residente do Hospital Municipal São José.

2. Chefe do Serviço de Residência Médica e Coordenador do Curso de Medicina da UNIVILLE; Coloproctologista.

3. Chefe do Departamento de Cirurgia Geral, Hospital Municipal São José, Cirurgião Torácico. 
análise comparativa estatística destes dois grupos revelou que os pacientes portadores de apendicite complicada apresentaram média de idade significativamente superior do que aqueles com apendicites não complicadas $(\mathrm{p}=0,01)$ (Gráfico 2).

Em relação ao período médio de internação observamos um tempo de permanência hospitalar superior nos pacientes com apendicites complicadas $(\mathrm{p}=0,01)($ Gráfico 3$)$.

\section{DISCUSSÃo}

A apendicite aguda é uma doença extremamente freqüente e com formas de apresentação diversas. Incide mais na faixa etária jovem, mas não raramente em mais idosos. $^{3}$ No nosso estudo $70 \%$ dos pacientes pertenciam ao sexo masculino e $58 \%$ dos pacientes tinham idade inferior a 31 anos.

Já está bem estabelecido por diversos estudos que a apendicite aguda nos pacientes mais idosos tende a apresentar evolução mais grave. ${ }^{4}$ Watters ${ }^{5}$ analisando 122 pacientes portadores de apendicite aguda, demonstrou um índice de perfuração apendicular três vezes maior naqueles com idade superior a 65 anos. Franz ${ }^{1}$ em um estudo com 100 pacientes encontrou um índice de apendicite aguda complicada de $88 \%$ em pacientes entre 50-70 anos e em pacientes com idade superior a 70 anos, mais da metade (52\%), apresentavam abscesso intra-abdominal. Pittman-Waller ${ }^{6}$ analisando um total de 5755 apendicectomias verificou um índice de apendicites complicadas de $32 \%$, maior em pacientes do sexo masculino e com idades mais avançada. No nosso estudo foi encontrada uma taxa de apendicites complicadas (gangrenosas e supuradas) de $53 \%$ em pacientes acima de 40 anos superior à taxa de $35 \%$ em pacientes com idade inferior a 40 anos.

Embora a maior parte dos pacientes com apendicite aguda permaneça pouco tempo nos hospitais, esta diferença de estágio evolutivo pode significar uma maior permanência hospitalar $^{2,7,8}$.

Nosso estudo encontrou uma diferença estatisticamente significante entre os pacientes com apendicites agudas complicadas e não-complicadas no que diz respeito ao tempo de internação hospitalar. Apendicites agudas não-complicadas envolveram um tempo médio de internação de 3,8 dias em comparação com as apendicites complicadas que tiveram um tempo de internação médio de cinco dias. Analisando o tempo de internação segundo a idade do paciente também encontramos um tempo médio de internação hospitalar maior em pacientes com mais de 40 anos quando comparado aqueles com menos de 40 anos $(7,1$ dias e 3,6 dias respectivamente).

Estes resultados sugerem a necessidade de uma maior ênfase e atenção aos pacientes mais idosos portadores de apendicites em estágios evolutivos mais avançados
Tabela 1 - Média de idade dos pacientes em anos e tempo médio de internação em dias, segundo classificação histopatológica (variação do intervalo entre parênteses).

\begin{tabular}{|c|c|c|}
\hline & Média de idade & $\begin{array}{l}\text { Tempo médio } \\
\text { de internação }\end{array}$ \\
\hline Catarral & $27,9 \quad(13-55)$ & $3,7(2-11)$ \\
\hline Flegmonosa & $28,4 \quad(13-65)$ & $3,9(2-30)$ \\
\hline Supurativa & $30,1 \quad(13-76)$ & $5 \quad(2-36)$ \\
\hline Gangrenosa & $35 \quad(13-61)$ & $5,2(2-10)$ \\
\hline
\end{tabular}

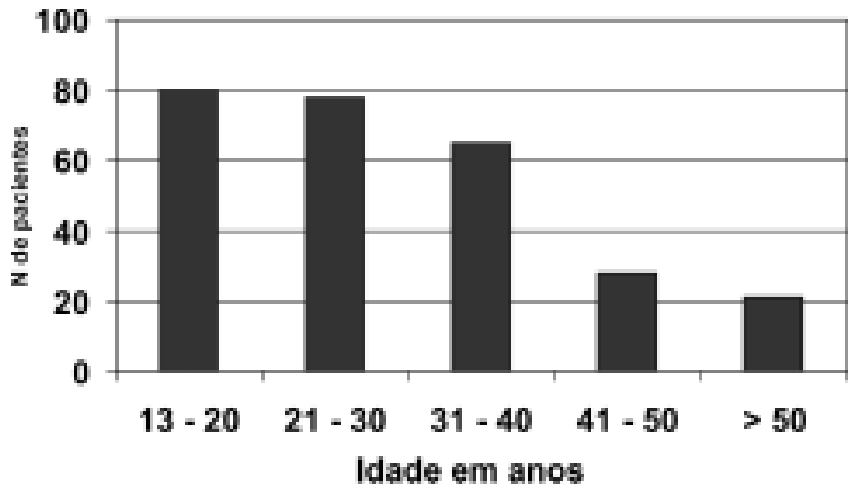

Gráfico 1 - Distribuição da frequência de apendicite segundo a idade em anos.

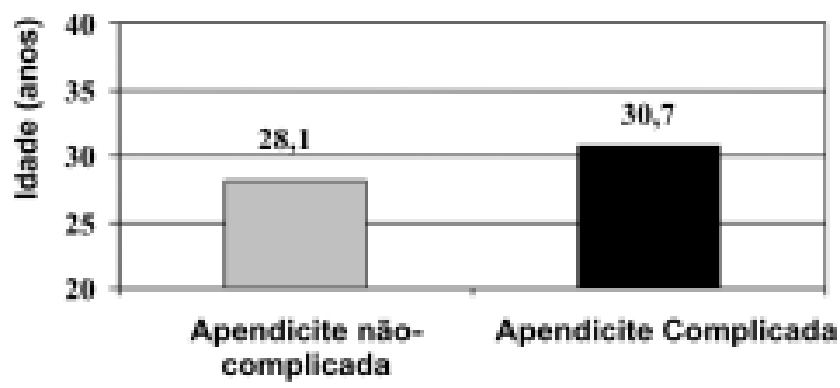

Gráfico 2 - Média de idade em anos relacionada com o tipo de apendicite.



Gráfico 3 - Tempo médio de internação em dias relacionado com o tipo de apendicite. 


\begin{abstract}
Background: Acute appendicitis is a very common disease and elderly people appears to carry the worst prognostic outcome. The objective of this paper is to identify a possible relation between the evolutive phase of the appendicitis, age of the patient and hospital length of stay. Methods: A total of 272 patients submitted to appendectomy were retrospectively evaluated regarding the evolutive phase of appendicitis, age of the patient and of hospital length of stay. The evolution of the inflammatory process was classified by the hystopathologic exam in four types: catarrhal, phlegmonous, suppurative and gangrenous. Results: Males were $193(70 \%)$ and the median age of all patients was 29 years. The mean hospital length of stay was 4.3 days. The incidence of the different evolution phases was: 88 cases (32.3\%) for catarrhal, 79 (29\%) for phlegmonous form, 70 (25.7\%) for suppurative and $35(12.8 \%)$ gangrenous. The analysis of the mean age and mean lenght of stay in the hospital was: 27.9 years and 3.7 days for the catarrhal type, 28.4 years and 3.9 days for phlegmonous type, 30.1 years and 5 days for the supurative type and 35 years and 5.2 days for the gangrenous type. When they were grouped, the mean age and length of stay were: 28.1 years and 3.8 for the group catarrhal + phlegmonous and 30.7 years and 5 days for the supurative + gangrenous group. There was statistical significance between the evolution phase of the appendicitis and the hospital length of stay $(p=0.01)$ and between age and evolution of the appendicitis ( $p=0.01)$. Conclusions: Patients with advanced evolutive phases of appendicitis trends to stay longer in hospital, tends particularly in older patients.
\end{abstract}

Key-words: Appendicitis; Age; Hospital stay.

\section{REFERÊNCIAS}

1. Franz MG, Norman J, Fabri PJ - Increased morbidity of appendicitis with advancing age. Am Surg. 1995;61(1):40

2. Ricci Ma, Trevisani MF, Beck WC - Acute appendicitis. A 5year review. Am Surg. 1991;57(5):301-5.

3 Addiss DG, Shaffer N, Fowler BS, et al. - The epidemiology of appendicitis and appendectomy in the United States. Am J Epidemiol. 1990;132(5):910-25

4. Watters JM, Blakslee JM, March RJ, et al. - The influence of age on the severity of peritonitis. Can J Surg. 1996;39(2):142-6

5. Redmond JM, Smith Gw, Wilasrusmee C, et al. - A new perspective in appendicitis: calculation of half time $(\mathrm{T}(1 / 2))$ for perforation. Am Surg. 2002;68(7):593-7.

6. Pittmann-Waller VA, Myers JG, Stewart RM, et al. Appendicitis: why so complicated? Analysis of 5755 consecutive appendectomies. Am Surg. 2000;66(6):548-54.
7. Ronchetto F, Azzario G, Pistono PG, et al. - Gangrenous and perforating appendicitis in a provincial hospital: a 48-month retrospective study. Clinical and microbiological aspects, course and postoperative morbidity. G Batteriol Virol Immunol. 1990;83(1-12):27-41

8. Blomqvist P, Ljung H, Nyren O, et al. - Appendectomy in Sweden 1989-1993 assessed by the Inpatient Registry. J Clin Epidemiol. 1998;51(10):859-65

Endereço para correspondência:

Dr. Mauro Pinho

Hospital São José

Rua Getúlio Vargas n.238

Bairro: Centro

89202-000- Joinville - SC

Telefone: 441-6553 (Rosemary)

E-mail: mpinho.joi@terra.com.br / carfis@terra.com.br 